\title{
HISTÓRIA, LITERATURA E A DITADURA BRASILEIRA: HISTORIOGRAFIA E FICÇÕES NO CONTEXTO DO CINQUENTENÁRIO DO GOLPE DE 1964
}

History, literature and Brazilian dictatorship: historiography and fictions in the context of the fiftieth anniversary of the 1964 coup

Historia, literatura y la dictadura brasileña: historiografía y ficciones en el contexto del cincuentenario del golpe de 1964

FERNANDO PERLATTO

http://dx.doi.org/10.1590/S2178-14942017000300011

Fernando Perlatto é mestre em Sociologia pelo Instituto Universitário de Pesquisas do Rio de Janeiro (IUPERJ), doutor em Sociologia pelo Instituto de Estudos Sociais e Políticos da Universidade do Estado do Rio de Janeiro (IESP/UERJ) e professor adjunto de História Contemporânea do Departamento de História e do Programa de Pós-Graduação em História da Universidade Federal de Juiz de Fora (UFJF).

Artigo recebido em 1 de junho e aprovado para publicação em 30 de agosto de 2017. 


\title{
RESUMO
}

Este artigo objetiva refletir sobre a relação entre história e literatura a partir da análise de romances que abordam a ditadura militar brasileira, publicados no Brasil no contexto do cinquentenário do golpe de 1964. Busca-se analisar de que maneira essas narrativas literárias, quando colocadas em diálogo com pesquisas acadêmicas recentes, contribuem para uma compreensão mais complexa e multifacetada de diferentes aspectos da ditadura militar, como a luta armada, o apoio de setores da sociedade civil na sustentação ao regime, o exílio e o cotidiano durante aquele período.

PalaVras-CHAVE: literatura; história; ditadura militar; cinquentenário; golpe de 1964.

\begin{abstract}
This article discusses the relationship between history and literature based on the analysis of novels that address the Brazilian military dictatorship, published in Brazil in the context of the fiftieth anniversary of the 1964 coup. It analyzes how these literary narratives, combined with recent academic research, contribute to a more complex and multifaceted understanding of different aspects of the military dictatorship, such as armed combat, the support of sectors of the civil society to the regime, the exile, and the daily life during that period.
\end{abstract}

KeY wORDS: literature; history; military dictatorship; fiftieth anniversary; 1964 coup.

\section{RESUMEN}

Este artículo objetiva reflexionar sobre la relación entre historia y literatura a partir del análisis de romances que abordan la dictadura militar brasileña, publicados en Brasil en el contexto del cincuentenario del golpe de 1964. Se busca analizar de qué manera esas narraciones literarias, cuando se ponen en diálogo con investigaciones académicas recientes, contribuyen a una comprensión más compleja y multifacética de diferentes aspectos de la dictadura militar, como la lucha armada, el apoyo de sectores de la sociedad civil en la sustentación al régimen, el exilio y el cotidiano durante ese período.

Palabras Clave: literatura; historia; dictadura militar; cincuentenario; golpe de 1964. 
m prefácio escrito em 1984 para o livro Uomani ad Aschwitz, de H. Langbein, traduzido para o português na coletânea $A$ assimetria e a vida, o escritor italiano Primo Levi, prisioneiro de Auschwitz, afirmava que a literatura sobre os campos de concentração nazistas podia ser grosso modo dividida em três grandes categorias: "diários ou memórias de deportados", "obras sociológicas e históricas", e "elaborações literárias" (Levi, 2016: 131). A combinação entre esses três gêneros discursivos possibilitaria uma visão mais plural, diversificada e complexa sobre a experiência traumática dos Lager.

Seria possível dialogarmos com esta divisão proposta por Levi para refletir sobre a bibliografia produzida acerca de um evento traumático da história brasileira, como a ditadura civil-militar. ${ }^{1}$ Ao longo das últimas décadas, diversas foram as "memórias", "obras sociológicas e históricas" e "elaborações literárias" que elegeram como temática ou cenário privilegiado a ditadura iniciada em 1964. Se vistas em conjunto, estas obras configuram uma bibliografia já ampla e diversificada, que vem buscando perscrutar, interpretar e compreender, a partir de prismas plurais, as razões do golpe, as características do regime autoritário que teve vigência a partir de então e seus desdobramentos para a democracia brasileira. ${ }^{2}$

Esta vasta literatura ganhou impulso renovado quando, em 2014, se completaram 50 anos do golpe de 1964. Datas redondas como esta se constituem como estímulos no sentido de, mediante a publicação de livros e coletâneas, organização de eventos e reportagens na imprensa, rememorar fatos traumáticos como o golpe civil-militar, lançando sobre ele novos olhares e leituras. Sob o impulso reflexivo desta efeméride, em 2014 e nos anos subsequentes os "discursos de memória" sobre este passado - para dialogar com categoria explorada por Andreas Huyssen (2000), em Seduzidos pela memória - adquiriram novo fôlego, e diversos foram os trabalhos memorialísticos, acadêmicos e ficcionais que afluíram no mercado editorial, contribuindo para lançar novos olhares e perspectivas sobre a ditadura, seus personagens, suas principais facetas e desdobramentos. ${ }^{3}$

\footnotetext{
1 Sobre a noção de evento traumático, ver Fico (2012).

2 Para um balanço bibliográfico sobre o tema, ver, entre outros, Fico (2004).

${ }^{3}$ Vale ressaltar que o cinquentenário do golpe de 1964 coincidiu com a finalização dos trabalhos da Comissão Nacional da Verdade (CNV), que lançou em dezembro de 2014 seu Relatório Final. Além disso, pari passu aos trabalhos a CNV, várias foram as comissões municipais e estaduais constituídas no bojo da CNV por setores da sociedade civil, que também contribuíram no sentido de conformar novos "discursos de memória" sobre o passado.
} 
No que concerne ao gênero da memorialística, o contexto do cinquentenário do golpe de 1964 impulsionou o relançamento ou novas publicações de autobiografias e testemunhos de pessoas que vivenciaram direta ou indiretamente o período ditatorial, contribuindo para expansão de um já amplo e diversificado conjunto de memórias sobre aquele período. Para além da reedição de obras já clássicas sobre o tema - a exemplo de 0 ato e 0 fato, de Carlos Heitor Cony, e O que é isso, companheiro?, de Fernando Gabeira, publicadas respectivamente em 2014 pela Nova Fronteira e em 2016 pela Estação Brasil -, houve a publicação de vários livros que buscaram, a partir de perspectivas diversas, lançar novas visões sobre a experiência autoritária brasileira. Exemplares nesse sentido foram as obras Tempos de turbilhão: relatos do golpe de 1964 (2014), organizada por Eric Nepomuceno, com textos de Darcy Ribeiro sobre a conjuntura do golpe de 1964 e seus desdobramentos; 1964: o golpe (2014), no qual o jornalista Flávio Tavares, também autor de Memórias do esquecimento, relembra acontecimentos e mudanças importantes no contexto do golpe de 1964; 50 anos esta noite (2014), autobiografia de José Serra, à época presidente da União Nacional dos Estudantes (UNE), na qual este relata as consequências do golpe de 1964 em sua trajetória pessoal e política; e Volto semana que vem (2015), narrativa biográfica na qual Maria Pilla reconstrói sua experiência como militante e exilada no contexto da ditadura. Há que se destacar também a publicação em anos mais recentes de obras memorialísticas de uma nova geração, constituída por filhos de pais que foram presos, torturados ou mortos pela repressão, destacando-se nesse sentido as obras Ainda estou aqui (2015), de Marcelo Rubens Paiva, e Em nome dos pais (2017), de Matheus Leitão.

Já no que diz respeito às "obras sociológicas ou históricas", para dialogar com os termos sugeridos por Primo Levi, a rememoração do golpe em 2014 testemunhou a publicação de diversos trabalhos acadêmicos e jornalísticos, quer individuais - com destaque para Ditadura e democracia no Brasil (Daniel Aarão Reis, 2014), O golpe de 1964. Momentos decisivos (Carlos Fico, 2014), 1964 (Jorge Ferreira e Angela de Castro Gomes, 2014), As universidades e o regime militar (Rodrigo Patto Sá Motta, 2014), 1964: história do regime militar brasileiro (Marcos Napolitano, 2014), A Casa da Vovó: uma biografia do DOI-Codi (Marcelo Godoy, 2014), Ditadura à brasileira (Marco Antônio Villa, 2014), Lugar nenhum (Lucas Figueiredo, 2015), Cova 312 (Daniela Arbex, 2015), Os porões da contravenção (Aloy Jupiara e Chico Otávio, 2016) e A ditadura acabada (Elio Gaspari, 2016) -, quer coletivos - a exemplo de $A$ ditadura que mudou o Brasil. 50 anos do golpe de 1964 (Daniel Aarão Reis et al., 2014), Ditaduras militares. Brasil, Argentina, Chile e Uruguai (Rodrigo Patto Sá Motta, 2014), À sombra das ditaduras (Brasil e América Latina) (Janaina Martins Cordeiro et al., 2014), História e memória das ditaduras no século XX 
(Samantha Quadrat e Denise Rollemberg, 2015), e 1964: do golpe à democracia (Angela Alonso e Miriam Dolhnikoff, 2015). ${ }^{4}$

A esta produção acadêmica e memorialística que ganhou destaque na efeméride do golpe de 1964, vieram se somar, para manter o léxico de Levi, a publicação em 2014 e nos anos subsequentes de diversas "elaborações literárias" que assumiram os anos da experiência autoritária brasileira como temáticas, contextos e cenários dessas narrativas. 0 presente artigo objetiva precisamente refletir sobre as narrativas construídas por algumas dessas produções ficcionais publicadas nesse contexto de rememoração. 0 intuito aqui é o de analisar de que maneira, ainda que mobilizando linguagens, objetivos e interesses diversos dos escritos memorialísticos e acadêmicos, essas narrativas literárias lançadas no mercado editorial a partir de 2014 contribuem sobremaneira para a conformação de determinados imaginários sobre a ditadura brasileira e seus desdobramentos que possibilitam uma compreensão mais multifacetada de suas características principais.

Não se tem a pretensão aqui de mapear e esgotar a análise de todos os romances publicados em e a partir da efeméride dos 50 anos do golpe em 2014. 0 que se busca é, a partir de um levantamento sistemático dos livros ficcionais lançados nesse contexto, selecionar e analisar algumas obras pertencentes ao gênero das "elaborações literárias" que evidenciam e corroboram a perspectiva quanto às potencialidades da literatura no sentido de, em diálogo com pesquisas acadêmicas, lançar novos olhares para a análise de um determinado período histórico, como a ditadura civil-militar brasileira. Para a construção do argumento aqui proposto, na primeira seção do artigo farei uma reflexão sobre literatura, eventos traumáticos e ditadura no Brasil, procurando, em diálogo com bibliografia pertinente, sopesar as potencialidades da mobilização de narrativas ficcionais para a análise histórica. Na segunda seção, a reflexão será direcionada para a análise de alguns livros de ficção produzidos a partir de 2014, no contexto da rememoração dos 50 anos do golpe de 1964, com o intuito de refletir de que maneira esses romances podem contribuir, em diálogo com trabalhos "sociológicos ou históricos", para uma interpretação mais complexa e multifacetada de diferentes aspectos da ditadura militar, como a luta armada, o apoio de setores da sociedade civil na sustentação ao regime, a experiência do exílio e o cotidiano durante aquele período.

\footnotetext{
${ }^{4}$ Para além dos livros autorais e coletâneas, há que se destacar a publicação, a partir da efeméride de 2014, de vários dossiês em revistas acadêmicas voltados para a discussão do golpe de 1964 e seus desdobramentos, a exemplo daqueles organizados pelas revistas Estudos Avançados (vol. 28, jan./abr.2014), Contemporânea (n.5, v.1, 2014), Margem Esquerda (n.22, 2014) e Perseu (edição especial março 2014).
} 


\section{LITERATURA, EVENTOS TRAUMÁTICOS E DITADURA BRASILEIRA}

inda nos anos 1960 e 1970, diversas foram as "elaborações literárias" que tiveram
o regime repressivo inaugurado em 1964 e questões a ele relacionadas, como a tortura e a luta armada, mobilizados como temáticas centrais ou estruturantes dos romances. Exemplares, nesse sentido, foram as obras Quarup (1960), Bar Don Juan (1971) e Reflexos do baile (1977), de Antonio Callado; Pessach: a travessia (1967), de Carlos Heitor Cony; Zero (1974), de Ignácio de Loyola Brandão (1974); A festa (1976), de Ivan Ângelo; e Em câmera lenta (1977), de Renato Tapajós. Nas décadas subsequentes, diferentes trabalhos procuraram analisar e compreender os traços e as características principais dessas narrativas ficcionais. Entre essas obras, destacam-se, entre outros, livros como Anos 70: literatura (1979), organizado, entre outros, por Heloisa Buarque de Hollanda, Literatura e vida literária (1985), de Flora Süssekind, O espaço da dor: o regime de 64 no romance brasileiro (1996), de Regina Dalcastagnè, Gavetas vazias: ficção e política nos anos 1970 (1996), de Tânia Pellegrini, Da urgência à aprendizagem: sentido da história e romance brasileiro nos anos 60 (1997), de Henrique Manuel Ávila, Itinerário político no romance pós-64 (1998), de Renato Franco, A história em seus restos: literatura e exílio no Cone Sul (2004), de Paloma Vidal, e, mais recentemente, $A$ literatura como arquivo da ditadura brasileira (2017), de Eurídice Figueiredo. ${ }^{5}$

A despeito das particularidades formais e temáticas dos romances produzidos no contexto dos governos autoritários, o que mais chamava atenção nessa literatura pós-1964 era, como destacado por Silviano Santiago (1989: 13), a "descoberta assustada e indignada da violência do poder". As ficções escritas naquela conjuntura, segundo o autor, seja na vertente "alegórica" e "jornalística", seja nos "romances reportagens", teriam aberto "campo para uma crítica radical e fulminante de toda forma de autoritarismo, principalmente aquela que, na América Latina, tem sido pregada pelas forças militares quando ocupam o poder" (Idem: 14). Nessa perspectiva, é coerente pensar que parte significativa da literatura produzida ao longo desses anos autoritários, para dialogar com Renato Franco (2003: 356), " pode ser considerada como uma forma de resistência", compreendendo "uma dimensão ética, enquanto manifestação de indignação radical diante do horror". A ficção escrita nesse contexto, como bem analisado por Eurídice Figueiredo (2017: 44), " pelo viés da subjetividade, mostra resíduos de experiências fraturadas pela violência do vivido".

Ainda que seja exagerado afirmar que a literatura seja "mais incisiva do que a historiografia" no sentido de se configurar como um "arquivo que guarda (...) a memória ainda

\footnotetext{
${ }^{5}$ Para uma análise dessa fortuna crítica, ver, entre outros, Ginzburg (2000) e Figueiredo (2017).
} 
dolorida de um tempo áspero e impróprio" - como o fazem Roberto Vecchi e Regina Dalcastagnè (2014) na apresentação do dossiê "Literatura e Ditadura", publicado na revista Estudos de Literatura Brasileira Contemporânea -, não restam dúvidas de que as narrativas ficcionais possibilitam lançar, via imaginação, novos olhares, perspectivas e interpretações sobre terrenos e territórios, sobretudo subjetivos, de uma forma como a produção acadêmica stricto sensu e até mesmo a memorialística não têm condições de fazer. Conforme destacam Vecchi e Dalcastagnè, a literatura se configura como um campo privilegiado a partir do qual se pode "praticar uma política do nome próprio em relação ao passado, em que a violência não se eufemiza nos disfarces linguísticos e pode declinar-se em todas as forças que a constituem" (Vecchi \& Dalcastagnè, 2014: 12). Ou indo mais além, as narrativas ficcionais evidenciam enorme potência para dar luz "aos restos, aos despojos, às ruínas e às destruições do passando, proporcionando uma monumentalidade alternativa" (Idem). Nessa perspectiva, a literatura, segundo os autores, abre caminhos para que se possa "reimaginar e narrar, inclusive no labirinto tormentoso de um passado que continua fugindo e não se deixa integralmente, ainda, apreender" (Idem).

Essa valorização da literatura como fonte para a compreensão do passado tem recebido cada vez mais atenção por parte da historiografia. Para além de reflexões teóricas produzidas por variados autores sobre a relação entre história e literatura, como Hayden White (1992), Roger Chartier (2001), Carlo Ginzburg (2002) e Luiz Costa Lima (2006), há também já uma produção significativa de trabalhos acadêmicos - para ficar apenas em dois exemplos, mencionemos Represálias selvagens: realidade e ficção na literatura de Charles Dickens, Gustave Flaubert e Thomas Mann, de Peter Gay, e Machado de Assis: historiador, de Sidney Chaloub -, que evidenciam as potencialidades da mobilização das narrativas ficcionais no sentido de descortinar aspectos e elementos importantes da estrutura social do passado e de dimensões subjetivas, que a produção acadêmica, muitas vezes, não tem condições de perscrutar. Para os historiadores, conforme enfatizado por Sidney Chalhoub e Leonardo Affonso de Miranda Pereira (1998: 7), a literatura deve ser pensada como um importante "testemunho histórico" e, uma vez compreendida como fonte, tem de ser devidamente interrogada e inquirida, apresentando enormes potencialidades para a análise de processos históricos determinados.

A literatura, até mesmo pela possibilidade do emprego de recursos formais diferenciados, como por exemplo o "deslocamento do foco narrativo e a suspensão da linearidade temporal", e pela utilização de procedimentos discursivos específicos, tem se mostrado particularmente frutífera do ponto de vista analítico para a elaboração de representações mais complexas e multifacetadas de experiências vividas sob governos autoritários - a exemplo do regime inaugurado com o golpe de 1964 -, diante da própria impossibilidade manifesta para 
que trabalhos acadêmicos consigam reconstruir, com a sensibilidade necessária, as atrocidades e os horrores desses momentos traumáticos (Ginzburg, 2000: 148). Além disso, há que se destacar que, em casos como o da ditadura brasileira, como decorrência das dificuldades de acesso a muitos dos "documentos sensíveis" daquele período (Fico, 2012), a literatura, "ao criar personagens, ao simular situações", pode, como bem ressaltado por Eurídice Figueiredo (2017: 29), cumprir o papel de uma espécie de "suplemento aos arquivos", ampliando as possibilidades para uma reflexão mais refinada sobre diferentes características daquele passado, que muitas vezes não podem ser acessadas e abordadas com o rigor necessário pelas pesquisas acadêmicas.

Conforme destacado por Márcio Seligmann-Silva (2003), a reconstrução do passado de contextos traumáticos exige uma nova "ética da representação" para buscar representar o irrepresentável da barbárie, uma ética que escape tanto do "positivismo inocente que acredita na possibilidade de se 'dar conta' do passado", quanto do "relativismo inconsequente que quer resolver a questão da representação eliminando o real" (Seligmann-Silva, 2003: 10). Neste movimento reflexivo, os discursos "denotativo-representativos" e os "literários", para dialogar com Seligmann-Silva, ainda que mantenham suas fronteiras e particularidades, podem ser mobilizados de forma articulada para uma compreensão mais complexa sobre 0 passado traumático. Partindo dessa perspectiva, pode-se sugerir que os textos ficcionais, ainda que sem a pretensão de substituir ou de se colocar como superiores às obras memorialísticas e acadêmicas, têm o potencial de contribuir para uma interpretação mais ampla e multifacetada do passado autoritário.

Desde a redemocratização do país, diversas foram as "elaborações literárias" publicadas que procuraram refletir sobre o golpe de 1964, a ditadura brasileira e seus desdobramentos. Ainda que essa produção ficcional não tenha sido tão extensa, sobretudo se partimos do pressuposto da centralidade que a experiência autoritária teve na história republicana brasileira - como parece sugerir o escritor Ricardo Lísias (2000) em sua reflexão sobre a literatura contemporânea no Brasil -, seria um equívoco não perceber que, ao longo das últimas décadas, ocorreu a publicação de romances relevantes, que tematizaram de maneira refinada aspectos diversos desse passado autoritário. Se, nos anos 1980, foram publicadas obras como Um romance de geração (1980), de Sérgio Sant'Anna, Em liberdade (1981), de Silviano Santiago, e Tropical sol da liberdade (1988), de Ana Maria Machado, que tematizaram a partir de perspectivas diversas o regime autoritário, nos anos 1990 e 2000, até mesmo pelo distanciamento temporal em relação àquele período, parece ter havido um crescimento do interesse por parte dos romancistas - muitos deles já nascidos quando a ditadura estava em processo de desmantelamento - em explorar ficcionalmente, mediante pontos de vistas heterogêneos, 
esse passado autoritário. Algumas obras literárias publicadas ao longo dessas décadas são exemplares bem acabados das narrativas construídas sobre o período autoritário, a exemplo de títulos como Amores exilados (1997), de Godofredo de Oliveira Neto, Não falei (2004), de Beatriz Bracher, História natural da ditadura (2006), de Teixeira Coelho, Soledad no Recife (2009), de Urariano Mota, Azul Corvo (2010), de Adriana Lisboa, O punho e a renda (2010), de Edgard Telles Ribeiro, K - Relato de uma busca (2011), de Bernardo Kucinski, Mar azul, de Paola Vidal (2012) e Vidas provisórias (2013), de Edney Silvestre.

0 que é interessante perceber é que a partir de 2014 houve uma espécie de boom na publicação de romances que elegeram a ditadura como contexto e cenário das narrativas ficcionais. Este boom pode estar associado ao interesse editorial no sentido de se aproveitar as rememorações em torno do cinquentenário do golpe de 1964 para a publicação de livros relacionados a esta temática, ou pode ser vinculado a um movimento geracional de escritores que não vivenciaram diretamente os anos repressivos e que vêm procurando, via ficção, lidar com esse passado autoritário. Menos do que investigar as razões para o retorno a este passado, o que me interessa particularmente na próxima seção é analisar os imaginários construídos sobre a experiência autoritária brasileira durante a ditadura em diferentes romances publicados a partir de 2014, na esteira da rememoração dos 50 anos do golpe de 1964. Sobretudo quando postas em diálogo com trabalhos acadêmicos recentes, essas obras literárias podem contribuir para lançar novos olhares sobre aspectos diferenciados das duas décadas da ditadura brasileira, como a luta armada, o apoio de setores da sociedade civil na sustentação ao regime, a experiência do exílio e o cotidiano durante aquele período.

\section{LITERATURA, HISTÓRIA E HISTORIOGRAFIA NO CONTEXTO DO CINQUENTENÁRIO DO GOLPE DE 1964}

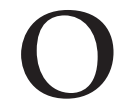

ano de 2014 e os subsequentes testemunharam a publicação de diversos romances que elegeram o golpe civil-militar de 1964 e a ditadura militar ali inaugurada como cenários, contextos e objetos centrais dos enredos narrados. Dentre essas obras ficcionais, é possível destacar, entre outros trabalhos, os livros Qualquer maneira de amar: um romance à sombra da ditadura (2014), de Marcus Veras; Damas da noite (2014), de Edgard de Telles Ribeiro; Tempos extremos (2014), de Miriam Leitão; A resistência (2015), de Julián Fuks; Palavras cruzadas (2015), de Guiomar de Grammont; Nuvem negra (2016), de Eliana Cardoso; De mim já nem se lembra (2016), de Luiz Rufatto; Quarenta dias (2014) e Outros cantos (2016), de Maria Valeria Rezende; Cabo de guerra (2016), de Ivone Benedetti; Os visitantes (2016), de 
Bernardo Kucinski; Lua de vinil, de Osmar Pilagallo (2016); Rio-Paris-Rio (2016), de Luciana Hidalgo, e Noite dentro da noite: uma autobiografia (2017), de Joca Reiners Terron.

Seria equivocado analisar esses romances como se conformassem todos eles um bloco homogêneo, sem fissuras e maiores diferenciações. No vasto conjunto de livros ficcionais que chegaram às prateleiras das livrarias a partir de 2014, quando das rememorações do cinquentenário do golpe civil-militar de 1964, há diferenças significativas, que se relacionam não apenas às abordagens e aos enfoques privilegiados, mas também ao que concerne mais especificamente à própria forma das obras literárias. 0 que é interessante apreender é de que maneira, dentro dessa heterogeneidade temática e formal, se percebe a conformação de diversos imaginários construídos sobre o golpe de 1964 e o período da ditadura, que, quando colocados em diálogo com a produção acadêmica recente, contribuem no sentido de lançar novos olhares sobre diferentes aspectos da experiência autoritária brasileira, como a luta armada, o apoio de setores da sociedade civil na sustentação ao regime, o exílio e o cotidiano durante aquele período.

Nesse sentido, é possível colocar os romances publicados a partir de 2014 em diálogo com algumas produções mais recentes no campo historiográfico, de modo a destacar de que maneira eles abrem perspectivas renovadas para a compressão sobre temáticas que vêm sendo objeto de debate e revisão dos estudos acadêmicos ao longo dos últimos anos. Uma temática exemplar nesse sentido é a luta armada. Se, ao longo dos anos 1970 e 1980, as abordagens referentes à luta armada permaneceram muito caudatárias das obras memorialísticas - a exemplo de O que é isso, companheiro? (1979), de Fernando Gabeira, e Combate nas trevas (1987), de Jacob Gorender -, ao longo dos anos 1990 e 2000 elas passaram a adquirir um perfil mais acadêmico, com destaque para trabalhos como $A$ revolução faltou ao encontro (1990), de Daniel Aarão Reis, O fantasma da revolução brasileira (1993), de Marcelo Ridenti, e $O$ apoio de Cuba à luta armada no Brasil(2001), de Denise Rollemberg. Respeitadas as diferenças e particularidades dessa produção historiográfica, importa destacar que esses trabalhos têm em comum a busca por tornar mais complexa a compreensão dos grupos armados no Brasil, rompendo tanto com uma visão homogênea dos seus participantes, quanto com uma perspectiva idealista que encarava esses grupos somente na chave virtuosa, idílica e heroica da resistência ao regime militar, destacando suas contradições e limites.

Muitos dos romances publicados a partir de 2014, na esteira da rememoração dos 50 anos do golpe de 1964, elegeram a luta armada como temática principal ou auxiliar de seus enredos, explorando, de um lado, a repressão que se abateu sobre seus participantes e, de outro, as contradições e limites dessa forma de resistência. No que concerne mais especificamente à dimensão repressiva, a quase totalidade dos romances mencionados está ancorada 
em narrativas que abordam, ainda que a partir de prismas e perspectivas diversas, a busca por informações, notícias e registros de familiares desaparecidos na ditadura. Se essa faceta desaparecimento/busca é estruturante em romances como Palavras cruzadas, de Guiomar de Grammont - que narra a busca da jornalista Sofia por informações do irmão Leonardo, desaparecido na Guerrilha do Araguaia - e Os visitantes, de Bernardo Kucinski - que retoma elementos do livro $K$ - Relato de uma busca (lançado originalmente em 2011 e relançado em 2016), abordando a busca de um pai pelo paradeiro da filha desaparecida durante a ditadura -, ela também está presente em outras das obras publicadas no contexto da rememoração do golpe de 1964.

Pode-se mencionar, nesse sentido, os romances Damas da noite, de Edgard de Telles Ribeiro - que toca no tema da busca do narrador pela localização da amiga de infância Helena, presa e torturada pela ditadura -, A resistência, de Julián Fuks - que passa pelo drama das Mães da Praça de Maio argentinas e pelo sofrimento da mãe do narrador em relação ao desaparecimento de sua amiga Martha María Brea no período autoritário -, Tempos extremos, de Miriam Leitão - que aborda a morte e o sumiço do marido de Alice, militante na época da ditadura -, Nuvem negra, de Eliana Cardoso - que se articula em torno do desaparecimento de Lotta, tia do personagem principal, Manfred, participante da Ação Popular -, Qualquer maneira de amar - que permeia a repressão e o desaparecimento de pessoas sem vínculos diretos com a luta armada -, Quarenta dias, de Maria Valeria Rezende - cuja personagem principal, Alice, se referencia em suas memórias ao marido Aldenor, um desaparecido político - e Noite dentro da noite, de Joca Reiners Terron - que aborda os sofrimentos causados nos familiares pelo sumiço de Karl Reiners na Guerrilha do Araguaia.

A faceta desaparecimento/busca produz nos familiares e amigos das vítimas "dor, constante, intensa, sem lenitivo", como destacado pela narradora Sofia de Palavras cruzadas. Essa dor se vincula às ausências várias causadas pelos desaparecimentos e pelas frustrações nas buscas, na falta de notícias, de informações e, até mesmo, dos próprios corpos das vítimas. Essas ausências, "ruínas silenciosas", decorrem, como bem colocado por Julián Fuks em $A$ resistência, da "atrocidade de um regime que mata também a morte dos assassinados": ou seja, "além de matar, [o regime] aniquila os que cercam suas vítimas imediatas, em círculos íntimos de outras vítimas ignoradas, lutos obstruídos, histórias não contadas" (Fuks, 2015: 78). Os familiares dos desaparecidos padecem não apenas do sofrimento decorrente da tortura, assassinato ou sumiço de seus entes, mas também dos estigmas associados àqueles que, porventura, tenham qualquer tipo de ligação, ainda que não direta, com a luta armada. Isso se manifesta, por exemplo, na necessidade de mudança de cidade por parte da personagem "rata", seu marido e seu filho em Noite dentro da noite, como decorrência da participação de 
seu irmão, Karl Reiners, na luta armada; no sumiço dos amigos da casa antes sempre visitada dos pais do narrador de $A$ resistência; ou nos preconceitos contra os parentes dos chamados "subversivos", que aparece em Palavras cruzadas.

As obras ficcionais publicadas a partir de 2014 contribuem para tornar mais complexa a compreensão de diversos aspectos relacionados à luta armada e às escolhas realizadas pelas pessoas naquele momento histórico. Em Cabo de guerra, por exemplo, Ivone Benedetti explora a figura ainda pouco estudada no campo acadêmico do chamado "cachorro", termo utilizado para se referir àquele militante infiltrado nas organizações, a serviço da ditadura, que traía e entregava seus companheiros, personagem que "tinha um nome de guerra em cada um dos lados" (Benedetti, 2016: 59), embora só estivesse efetivamente comprometido com um dos lados da guerra, ou seja, com o regime militar. Já em Os visitantes, um dos personagens que aparece para conversar com o autor narrador é Manuel Alves Lima, roteirista de tevê, acusado de ter entregado "mais de trinta, quem era e quem não era" (Kucinski, 2016: 33). Da mesma forma que o "cachorro" de Cabo de guerra justifica suas ações tendo em vista a sua sobrevivência no contexto da época, Manuel Alves Lima, quando confrontado pelo autor narrador sobre seu comportamento, responde: "A primeira coisa que todos dizem é que não entregaram ninguém, mas a maioria entregou, e sabe por quê? Porque eles nos levavam à loucura! À loucura! (...) 0 que você sabe sobre tortura? Nada! Absolutamente nada!" (Idem: 35). Ainda que esses romances estejam longe de justificar as escolhas dos personagens - enfatizando, inclusive, as consequências dos posicionamentos dos "cachorros" e dos delatores em termos de prisões, torturas e mortes -, eles complexificam o olhar sobre aquele momento e chamam a atenção para o fato de que, naquela conjuntura específica, as decisões eram mais complicadas do que uma análise a posteriori poderia supor.

Da mesma forma, muitas das ficções mencionadas anteriormente contribuem para chamar atenção para a heterogeneidade de pessoas que se engajaram na luta armada. Ao contrário de uma visão homogeneizante, que concebe aqueles que participaram de grupos armados como dotados de perfis e características iguais ou semelhantes, o que se vislumbra nos personagens que compõem vários dos romances aqui analisados é uma diversidade de personalidades, indo desde militantes convictos de suas causas - como Leonardo, de Palavras cruzadas, Rodolfo, de Cabo de guerra, Lotta, de Nuvem negra, Helena, de Damas da noite, Ana, de Ke Os visitantes, e Karl Reiners, de Noite dentro da noite - até figuras como o protagonista de Cabo de guerra, um "sujeito sem convicções", que se vê "de repente enredado num bando de arrebatados amigos, mimetizado" (Benedetti, 2016: 30), passando por "simpatizantes" da luta armada, como Maro, o protagonista de Qualquer maneira de amar, romance de Marcus Veras. 
Nessa perspectiva, é possível dizer que as obras literárias possibilitam, em certo sentido, dar carne e concretude a esses personagens, que muitas vezes são pensados em abstrato, evidenciando não apenas as diversidades existentes entre eles, mas também as várias dúvidas, questionamentos e dilemas vividos por aqueles que escolheram o caminho da luta armada. Essa dimensão relacionada às dúvidas e dilemas fica evidente, por exemplo, no romance Palavras cruzadas, quer seja na personagem Mariana, repleta de inseguranças sobre suas decisões em relação ao engajamento naquele conflito ou sobre ter ou não um filho em meio à Guerrilha do Araguaia, quer seja no personagem Leonardo, que se sente profundamente culpado por ter participado de um episódio de justiçamento contra um militante acusado de traição ao grupo ao qual pertencia.

O justiçamento, aliás, aparece como um tema atravessado por tabus e dificuldades no sentido de ser devidamente pensado e enfrentado como um grave problema não apenas pelos militantes - como se percebe na leitura de Os visitantes, de B. Kucinski -, mas também pelos familiares, a exemplo dos sentimentos de decepção e revolta da jornalista Sofia em Palavras cruzadas ao descobrir sobre a participação do irmão Leonardo no assassinato de um militante acusado de traidor. Além do justiçamento, outros limites, incoerências e contradições da luta armada podem ser depreendidos da leitura de vários desses romances, a exemplo dos discursos militaristas e sectários, que quase se aproximavam da retórica anticomunista direcionada pelos militares contra os setores progressistas naquela conjuntura. Isso aparece com destaque em Rio-Paris-Rio, de Luciana Hidalgo, quando a protagonista Maria se surpreende com a frase dita por um militante admirador da luta armada - "Devemos apoiar tudo o que o inimigo combate e combater tudo o que o inimigo apoia!" -, que soa aos seus ouvidos como se fosse pronunciada pelo seu avô militar: "As palavras soam tão militarescas que poderiam representar o slogan de qualquer exército do mundo. Mas, não, é de um revolucionário comunista. Há aí um mistério, ou equívoco" (Hidalgo, 2016: 73). Ao discurso militarista se somava a postura quase mística e religiosa assumida por alguns militantes, que se portavam, como sugerido em Cabo de guerra, como "monges sem hábito, teólogos incréus, atores de algum mistério de teatro iluminista" (Benedetti, 2016: 87).

Outras limitações daqueles que se engajaram na luta armada se relacionam, em primeiro lugar, à leitura equivocada e às esperanças de resistência armada que muitos militantes da esquerda tiveram no momento mesmo do golpe de 1964, como se vislumbra com o personagem Karl Reiners e seus camaradas em Noite dentro da noite - "Em sua imaginação, àquela altura camponeses de todo o país se uniam aos estudantes e a classe média se levantava em massa para combater os militares que haviam usurpado o poder legítimo de João Goulart" (Terron, 2017: 124). Em segundo lugar, essas limitações se concretizavam na própria 
incapacidade daqueles que se engajaram na resistência à ditadura no sentido de estabelecer um "canal de comunicação" com os pobres e oprimidos, "cuja experiência de um mundo duramente concreto contradizia qualquer ideário abstrato, importado de fora para dentro e de cima para baixo", como explicita a personagem Maria em Outros cantos (Rezende, 2016: 145). Os limites e contradições vão ficando cada vez mais expostos à medida que as forças da ditadura ampliam o cerco e a repressão contra os militantes. Em A resistência, o narrador questiona: "Como ninguém notava que já não discutiam novas táticas, rumo à muito maltratada nova sociedade, como ninguém notava que aquilo se convertera numa clínica do fracasso? Como não percebiam que a política se reduzia, nesses encontros tormentosos, ao mero grito agônico?" (Fuks, 2015: 80).

Além da luta armada, outro aspecto que vem sendo bastante explorado pelos estudos acadêmicos recentes dedicados à ditadura - na esteira, ressalte-se, das investigações abertas por René Dreyfuss em 1964, a conquista do Estado (1981), em que este analisa, entre outros aspectos, o papel de organizações civis como o Instituto de Pesquisas e Estudos Sociais (IPES) naquele contexto - diz respeito à investigação acerca do apoio que diversos setores da sociedade civil-como empresários, jornalistas, intelectuais, religiosos, políticos - asseguraram tanto ao golpe de 1964 quanto ao regime que se instaurou no país a partir de então. Esse apoio se manifestaria, segundo esses pesquisadores, em diversos momentos, ocasiões e eventos, como nas Marchas da Família com Deus pela Liberdade, que ocorreram em 1964, mobilizando milhares de pessoas em apoio ao golpe; nos índices de popularidade desfrutados pelo general Garrastazu Médici no momento mais repressivo dos "anos de chumbo", sobretudo como decorrência do chamado "milagre econômico"; assim como nas expressivas votações obtidas pelo partido de sustentação ao regime, a Aliança Renovadora Nacional (Arena), até mesmo nas eleições de 1978, as últimas realizadas sob a ditadura. Justamente por trazerem em seu bojo a reflexão sobre o papel desempenhado por setores da sociedade civil durante aquele período, alguns autores têm preferido utilizar os conceitos de "golpe civil-militar" e "ditadura civil militar" para dar conta das complexidades daquele momento (Aarão Reis, 2010).

Nessa chave interpretativa - cujas elaborações mais sistemáticas podem ser encontradas nos artigos que compõem a coletânea $A$ construção social dos regimes autoritários. Legitimidade, consenso e consentimento no século XX(2010), organizada por Denise Rollemberg e Samantha Quadrat -, o que se busca é pensar a ditadura como um regime autoritário construído socialmente, a partir do apoio e da sustentação de diferentes segmentos da sociedade civil. Concorde-se ou não com a utilização dos termos "golpe civil-militar" e "ditadura civil militar", o que interessa destacar, para o argumento aqui mobilizado, é que diversas pesquisas acadêmicas têm procurado ressaltar que a ditadura brasileira não pode ser interpretada 
como um movimento imposto por poucos vilões militares ou por um Estado que se sobrepôs à sociedade civil, enquanto esta assistia passivamente a esse movimento ou somente reagia a ele, mas deve, antes, ser compreendida a partir destas múltiplas e complexas relações que se estabelecem entre setores que apoiaram e interagiram com o regime inaugurado em 1964.

Os romances publicados a partir de 2014, quando da rememoração do cinquentenário do golpe de 1964, abrem possibilidades várias para que vislumbremos e compreendamos a partir de novas perspectivas os apoios de setores da sociedade civil à ditadura brasileira. 0 suporte conferido pelos empresários e suas relações com o regime autoritário aparecem, por exemplo, no livro Cabo de guerra, quando a personagem Samira, ao abordar as relações de seu marido empresário, Paolo, com o poderoso coronel, diz que eles fazem parte de "uma espécie de clube" voltado para o "combate à subversão, essas coisas, o Paolo e outros entram com dinheiro, o coronel tem contatos" (Benedetti, 2016: 107). Esse é um dos temas também presentes em Damas da noite, a partir do personagem João Oswaldo Albuquerque, empresário que participa diretamente da Operação Bandeirante (Oban), que, tal como o empresário Henning Albert Boilesen, financiava no final dos anos 1960 as operações de combate e repressão às organizações de luta armada em São Paulo. É possível depreender também da leitura de Nuvem negra as relações que se estabelecem entre uma grande empresa de engenharia controlada pelo sogro do personagem principal, Manfred, e o regime militar, fazendo eco às pesquisas desenvolvidas por Pedro Henrique Pereira de Campos, Estranhas catedrais: as empreiteiras brasileiras e a ditadura civil-militar (2014).

0 apoio de setores, no interior das universidades, que deram sustentação à ditadura, delatando alunos e professores, sendo coniventes com processos de aposentadoria, exonerações e perseguições por razões ideológicas - que vem sendo analisado em pesquisas como As universidades e o regime militar (2014), de Rodrigo Patto Sá Motta - aparece, por exemplo, com clareza em K. e em Os visitantes, de B. Kucinski, cujos enredos giram em torno da filha de K., Ana, desaparecida durante a ditadura quando era professora de Química da Universidade de São Paulo, e demitida da instituição "por abandono de função" com a conivência da Congregação, órgão supremo do Instituto de Química da USP. Nestes mesmos livros, Kucinski toca ainda no apoio direto ou no silenciamento de setores religiosos ao que acontecia no país naquela conjuntura. Em Os visitantes, o autor narrador diz que, em geral, "os judeus foram indiferentes" à repressão: as entidades judaicas, segundo ele, "não apoiaram o golpe, ao contrário de muitas entidades católicas e dos empresários, mas também não o denunciaram, e assim se mantiveram no decorrer de toda a ditadura, até nos momentos mais pesados" (Kucinski, 2016: 64).

Já o apoio dado por jornalistas ao regime militar - que vem sendo investigado por diferentes trabalhos acadêmicos, com destaque especial para Cães de guarda. Jornalistas e 
censores (2004), de Beatriz Kushnir - ganha ênfase em livros como Damas da noite, cujo protagonista narra, com pesar, seu processo gradativo de colaboração e adesão ao que ele mesmo chama de "esquema dominante". Essa perspectiva contribui para romper com uma memória construída sobre a imprensa naquele período segundo a qual todos os setores da mídia teriam ou sofrido censura ou resistido à repressão, evidenciando que as relações eram muito mais ambíguas e repletas de matizes. Para além dos empresários, intelectuais, religiosos e jornalistas, 0 apoio ao regime militar no dia a dia também pode ser vislumbrado no romance Lua de vinil, quando o personagem Amaral, ao assistir, em um local público, a um discurso de Médici na televisão, meneia "a cabeça várias vezes em aprovação" e comenta "em voz alta não entender como alguém podia ser contra um regime que tinha o objetivo de melhorar a qualidade de vida do povo. Pois não era exatamente isso o que nosso presidente Médici estava dizendo?" (Pilagallo, 2016: 80).

Assim como ocorre em relação às temáticas da luta armada e do apoio de setores da sociedade civil ao golpe de 1964 e à ditadura então instaurada no país, as pesquisas acadêmicas também têm avançado na investigação sobre outras questões importantes acerca daquele período, como, por exemplo, a experiência do exílio e o cotidiano durante o regime militar. No que diz respeito mais especificamente à temática do exílio, diversos trabalhos - a exemplo da obra Exílio: entre raízes e radares (1999), de Denise Rollemberg, e da coletânea Caminhos cruzados: história e memória dos exilios latino-americanos no século XX (2011), organizada por Samantha Quadrat - vêm procurando destacar os variados impactos e as consequências sobre as vidas daqueles que foram forçosamente obrigados ou levados a deixar o país, deslocando-se para outras geografias. A dramática dúvida entre permanecer no país ou partir aparece, por exemplo, em $A$ resistência, quando, após muito pensarem, os pais do narrador decidem que "partir era o que deviam fazer, sem nem passar em casa. Partir, só os dois e o menino, só os três e o que levavam nos bolsos, as roupas do corpo, uma mochila com a mamadeira cheia e um punhado de fraldas" (Fuks, 2015: 82).

Maria, a protagonista de Rio-Paris-Rio, exilada em Paris, reflete continuamente sobre sua condição, compreendendo-se como "um estar-no-mundo-entre-mundos" (Hidalgo, 2016: 10). Quando Maria compreende que o próprio "termo francês étranger, usado para estrangeiro, significa também estranho, aquele que destoa do meio", diz a autora, ela "entendeu tudo. Todo estrangeiro é um intruso, ela sabe" (Idem: 45, grifos da autora). A necessidade de se mudar e de se adaptar a cada nova circunstância como decorrência do arbítrio se manifesta também, ainda que de forma menos explícita, em Outros cantos, de Maria Valéria Rezende, nas recordações da protagonista Maria, que sempre se lembra de um homem - que não sabemos se é a mesma pessoa, embora possua sempre o mesmo olhar -, que ela reencontra 
em diferentes momentos da sua vida, com nomes diferentes, como a indicar aqueles que participaram da resistência ao regime, escondidos em diferentes lugares do país e do mundo, valendo-se de disfarces e fugas, para escapar dos agentes da repressão. Já os impactos sobre os filhos dos exilados nos fazem refletir sobre outras consequências da repressão, que não se manifestam somente naqueles que foram seus alvos diretos, mas também em seus descendentes. Pergunta o narrador de $A$ resistência, filho de exilados argentinos: "Pode um exílio ser herdado? Seríamos nós, os pequenos, tão expatriados quanto nossos pais? (...). Estará também a perseguição política submetida às normas da hereditariedade?" (Fuks, 2015: 19).

No que concerne às dimensões do cotidiano, diversas pesquisas vêm procurando perscrutar as vivências no dia a dia durante o período autoritário, de modo a tornar mais complexas e abrangentes as diferentes experiências de vida naquele contexto. ${ }^{6}$ Quando se desloca 0 olhar das grandes estruturas e transformações que tiveram curso naquele período, ou dos atores políticos e sociais que ganharam protagonismo naquela conjuntura - a exemplo daqueles que atuaram diretamente na repressão ou na resistência ao regime - e se direciona a atenção para "baixo", isto é, para as milhares de pessoas que seguiam suas vidas muitas vezes quase que indiferentes ao que ocorria politicamente no país, tem-se um quadro mais multifacetado dos anos do regime militar no Brasil. Nesse sentido, é particularmente interessante mencionar o livro de Luiz Ruffato, De mim já nem se lembra, que aborda o período ditatorial de um ponto de vista ainda pouco explorado pelos estudos acadêmicos, na medida em que elege como protagonista José Célio, um operário pertencente à classe média baixa que apenas gradativamente vai tomando consciência da situação vivenciada pelo país naqueles anos.

Ainda que pesquisas acadêmicas sobre os trabalhadores no período da ditadura tenham avançado de forma significativa ao longo dos últimos anos, ${ }^{7}$ há ainda poucas abordagens dedicadas à análise de personagens como José Célio, do livro De mim já nem se lembra. A partir de cartas trocadas pelo protagonista do romance com sua mãe entre 1971 e 1978, é possível analisar as relações cotidianas de um trabalhador "comum" naquela conjuntura, envolvido com preocupações diferentes daquelas mais imediatamente vinculadas à vida política do país, como seus namoros e paixões frustradas, suas expectativas e conflitos no trabalho, sua visão religiosa, seus momentos de lazer, suas perspectivas em relação às trajetórias de seus familiares, sua paixão pelo futebol, entre outros aspectos. Somente com o passar dos anos, à medida que o livro avança na narrativa, é que José Célio vai tomando consciência da situação repressiva e desigual do país, a partir de situações diversas, como as conversas com

\footnotetext{
${ }^{6}$ Sobre este tema, ver, entre outros, Almeida \& Weis (1998).

${ }^{7}$ Sobre o tema, ver, entre outros, Fontes \& Correa (2016).
} 
o cunhado Fabinho, a agressão e desaparecimento de um conhecido, Norivaldo, que morava na mesma pensão em que ele vivia, e o envolvimento com a luta sindical, a organização de assembleias, de campanhas salariais e greves. Em carta enviada em dezembro de 1976 à sua mãe, José Célio rompe com as narrativas do cotidiano e diz: "a senhora sabe que a gente vive debaixo de uma ditadura que prende e mata trabalhadores, que a única coisa que querem é mudar a situação injusta do país, mas a senhora nem fale isso aí em Cataguases não, senão eles ainda prendem a senhora e dizem que a senhora é comunista" (Ruffato, 2016: 114).

\section{CONCLUSÃO}

inda que os últimos anos tenham testemunhado a produção de diversos livros voltados
para a compreensão da ditadura militar brasileira, bem como a ampliação de debates e reflexões sobre seus significados e consequências para a democracia no país, é forçoso reconhecer que ainda há um amplo desconhecimento de setores da população sobre esse período. Esse desconhecimento - resultado, talvez, da ausência, ou, pelo menos, da escassez de políticas de memória mais significativas orientadas no sentido de rememorar, a partir de diferentes perspectivas, os aspectos repressivos e contraditórios desse passado - tem consequências perversas, como se observa na legitimidade crescente de discursos na esfera pública que defendem abertamente se não o retorno da ditadura, ao menos a utilização de soluções autoritárias para os problemas do país. Nesse sentido, torna-se imperativa a mobilização de diversos meios e instrumentos que contribuam não apenas para uma compreensão mais complexa sobre a ditadura militar brasileira, mas também para a sensibilização, sobretudo das novas gerações, sobre esse passado cujas permanências ainda se fazem presentes em nossa cultura política autoritária.

Se considerarmos os romances publicados no Brasil a partir de 2014, quando da rememoração do cinquentenário do golpe de 1964, que elegeram os anos do regime autoritário como cenários e contextos, é possível afirmar que, em sua heterogeneidade, eles se constituem em importantes meios no sentido de possibilitar uma interpretação mais multifacetada de aspectos diversos da ditadura militar, como a luta armada, o apoio de setores da sociedade civil na sustentação ao regime, o exílio e o cotidiano durante aqueles anos, além de se conformarem em instrumentos importantes de sensibilização de um público mais amplo, especialmente extra-acadêmico, em relação às arbitrariedades daquele período. Ainda que seja possível destacar algumas limitações do conjunto de romances analisados neste artigo, que não tivemos condições de explorar de forma mais sistemática - a exemplo do excesso de didatismo de alguns trabalhos e do foco excessivo na experiência da classe média, secundarizando, 
salvo raras exceções, as vivências de personagens oriundos do mundo popular -, essas "obras literárias", para retomar os termos de Primo Levi mobilizados no início do texto, sobretudo quando articuladas aos "diários e memórias" e às "obras sociológicas e históricas", apresentam enormes potencialidades que devem ser exploradas e aproveitadas pelos pesquisadores e leigos interessados em compreender as múltiplas facetas da ditadura brasileira.

\section{REFERÊNCIAS BIBLIOGRÁFICAS}

AARÃO REIS, Daniel. Ditadura, anistia e reconciliação. Estudos Históricos, vol. 23, n. 45, janeiro-junho 2010, p.171-186.

ALMEIDA, Maria Hermínia T. de \& WEIS, Luís. Carro zero e pau-de-arara: o cotidiano da oposição de classe média ao regime militar. In: SCHWARCZ, Lilia Moritz (org.). História da vida privada no Brasil: contrastes da intimidade contemporânea. Vol. 4. São Paulo: Cia. das Letras. 1998, p. 319-409.

BENEDETTI, Ivone. Cabo de guerra. São Paulo: Boitempo, 2016.

CHALHOUB, Sidney \& PEREIRA, Leonardo Affonso de Miranda. Apresentação. In: A história contada: capítulos de história social da literatura no Brasil. Rio de Janeiro: Nova Fronteira, 1998, p. 7-13.

CHARTIER, Roger. Cultura escrita, literatura e história. Porto Alegre: Artmed, 2001.

FICO, Carlos. Além do golpe: versões e controvérsias sobre 1964 e a ditadura militar. Rio de Janeiro: Record, 2004.

História do tempo presente, eventos traumáticos e documentos sensíveis: o caso brasileiro. Varia História, vol. 28, p.43-59, 2012.

FIGUEIREDO, Eurídice. A literatura como arquivo da ditadura brasileira. Rio de Janeiro: 7 Letras, 2017.

FONTES, Paulo \& CORREA, Larissa. As falas de Jerônimo: trabalhadores, sindicatos e historiografia da ditadura militar brasileira. Anos 90, vol. 23, 2016, p. 129-151.

FRANCO, Renato. Literatura e catástrofe no Brasil: anos 70. In: Seligmann-Silva, Márcio. História, memória, literatura: o testemunho na era das catástrofes. Campinas: Editora UNICAMP, 2003, p. 355-374.

FUKS, Julián. A resistência. São Paulo: Companhia das Letras, 2015.

GINZBURG, Carlo. Relações de força: história, retórica, prova. São Paulo: Companhia das Letras, 2002.

GINZBURG, Jaime. Escritas da tortura. In: Telles, Edson \& Safatle, Vladimir (org.). O que resta da ditadura. São Paulo: Boitempo, 2010, p.133-149.

HIDALGO, Luciana. Rio-Paris-Rio. Rio de Janeiro: Rocco, 2016.

HUYSSEN, Andreas. Seduzidos pela memória. Arquitetura, Monumentos, Mídia. Rio de Janeiro: Aeroplano, 2000.

KUCINSKI, Bernardo. Os visitantes. São Paulo: Companhia das Letras, 2016.

LEVI, Primo. A assimetria e a vida. Artigos e ensaios. 1955-1987. São Paulo: Editora UNESP, 2016. 
LIMA, Luiz Costa. História. Ficção. Literatura. São Paulo: Companhia das Letras, 2006.

LISIAS, Ricardo. Dez fragmentos sobre a literatura contemporânea no Brasil e na Argentina ou de como os patetas sempre adoram o discurso do poder. In: Telles, Edson \& Safatle, Vladimir (org.). O que resta da ditadura. São Paulo: Boitempo, 2010, p. 319-328.

PILAGALLO, Oscar. Lua de vinil. São Paulo: Seguinte, 2016.

REZENDE, Maria Valéria. Outros cantos. São Paulo: Alfaguara, 2016.

SANTIAGO, Silviano. Nas malhas da letra. São Paulo: Companhia das Letras, 1989.

SELIGMANN-SILVA, Márcio. Introdução. In: ——. História, memória, literatura: o testemunho na era das catástrofes. Campinas: Editora UNICAMP, 2003, p.7-44.

TERRON, Joca Reiners. Noite dentro da noite: uma autobiografia. São Paulo: Companhia das Letras, 2017.

VECCHI, Roberto \& DALCASTAGNÈ, Regina. Apresentação. Estudos de Literatura Brasileira Contemporânea. Literatura e Ditadura, Brasília, n. 43, jan-jun, 2014, p.11-12.

WHITE, Hayden. Metahistória: a imaginação histórica da Europa do século XIX. São Paulo: Edusp, 1992. 